\title{
Supranormal dietary folic acid supplementation: effects on methionine metabolism in weanling rats
}

\author{
M. Achón, E. Alonso-Aperte, N. Úbeda and G. Varela-Moreiras* \\ Departamento de Nutrición, Bromatología y Tecnología de los Alimentos, Facultad de Farmacia, Universidad San Pablo-CEU, \\ 28668 Boadilla del Monte, Madrid, Spain
}

(Received 15 June 2006 - Revised 9 February 2007 - Accepted 20 February 2007)

\begin{abstract}
There are nationwide folic acid (FA) fortification programmes of staple foods established or under consideration in order to prevent neural tube defects. Universal FA fortification still remains controversial because of the concern that additional FA in the diets of population groups (e.g. children and elderly) not initially targeted for fortification may suffer adverse effects. However, dietary surveys regarding folate generally deal with adults and little is known about the consumption and long-term effects of fortified food and supplements in growing individuals. Recent reports from our laboratory show several effects of high-dose folate supplementation in rats. In the present work, we studied the effect of FA on the methionine cycle in weanling (3-week-old) male rats after 4 weeks of supplementation with $40 \mathrm{mg}$ FA/ $\mathrm{kg}$ diet $v$. control (1 mg FA/kg diet). FA supplementation resulted in a reduction of homocysteine and creatinine concentrations $v$. control group. FA supplementation did not alter $S$-adenosylmethionine/ $S$-adenosylhomocysteine ratio, DNA methylation, enzymatic activities or concentrations of vitamins involved in the nutritional regulation of the methionine cycle, except for folate. FA supplementation of $40 \mathrm{mg} / \mathrm{kg}$ did not lead to hepatic or renal damage. In conclusion, there were no apparent adverse effects on one-carbon metabolism after FA supplementation in the studied conditions.
\end{abstract}

Folic acid supplementation: Methionine cycle: Homocysteine: Weanling rats

Folic acid (FA) supplementation or food fortification began in the USA on 1 January 1998 (Food \& Drug Administration, 1996), because of its effect on the prevention of neural tube defects (MRC Vitamin Study Research Group, 1991; Czeizel \& Dudas, 1992) and the potential association with reduced risk for vascular disease (Homocysteine Lowering Trialists' Collaboration, 2005) and cancer (Giovanucci et al. 1998). Canada, Chile and Israel have more recently started universal mandatory FA fortification (Giovanucci et al. 1998; Bailey et al. 2003). Public health policies promoting daily intake of FA supplements by women of childbearing age have not resulted in increased supplement use. In contrast, food fortification has been associated with a reduction in neural tube defect rates in the USA of approximately $26 \%$ (Centers for Disease Control \& Prevention, 2004) and in Canada up to $54 \%$ (Persad et al. 2002; Ray, 2004). However, there is some limited evidence to suggest that additional FA in the diets of population groups (e.g. children and elderly) not initially targeted for fortification may suffer adverse effects. Such concern is mainly focused on the potential masking of vitamin $B_{12}$ deficiency, a condition that affects $10-15 \%$ of the population over age 60 (Bailey et al. 2003). Except for this concern, FA is mainly considered a non-toxic vitamin (Bailey \& Berry, 2005). However, in man, although the currently available data are not sufficient, it has been hypothesized that excess folate may enhance the development and progression of already existing, undiagnosed premalignant and malignant lesions (Sohn et al. 2003; Kim, 2004). It has also been recently reported that unmetabolized FA in plasma is associated with decreased natural killer cytotoxicity among postmenopausal women (Troen et al. 2006). In addition, few data exist on the potential effect of long-term high FA intake in children and teenagers. In rats, diets containing $40 \mathrm{mg} \mathrm{FA} / \mathrm{kg}$ diet (20 times the recommended dietary concentration for rats) accelerated cancer progression in rodent models of cancer (Kim et al. 1996; Song et al. 2000; Kim, 2004). Recent data from our group showed also a negative effect of high-dose FA supplementation on dietary metabolic protein utilization in pregnant and virgin rats as well as in aged rats, suggesting that the vitamin may act under these conditions as a xenobiotic more than as a nutrient (Achón et al. 1999, 2000, 2002). Folate coenzymes are involved in many processes including DNA synthesis, normal cell division, purine synthesis and amino acid interconversions, especially in growing individuals (Institute of Medicine, 1998). FA plays a critical role in the nutritional regulation in methionine metabolism (Fig. 1). By donation of a methyl group, 5-methyltetrahydrofolate participates in the synthesis of methionine in the reaction catalysed by the vitamin $\mathrm{B}_{12^{-}}$ dependent methionine synthase (MS). Methionine acts as a

\footnotetext{
Abbreviations: BHMT, betaine homocysteine methyltransferase; FA, folic acid; MAT, methionine adenosyltransferase; MS, methionine synthase; SAH, $S$-adenosylhomocysteine; SAM, $S$-adenosylmethionine.

* Corresponding author: Dr Gregorio Varela-Moreiras, fax +34 9135104 75, email gvarela@ceu.es
} 


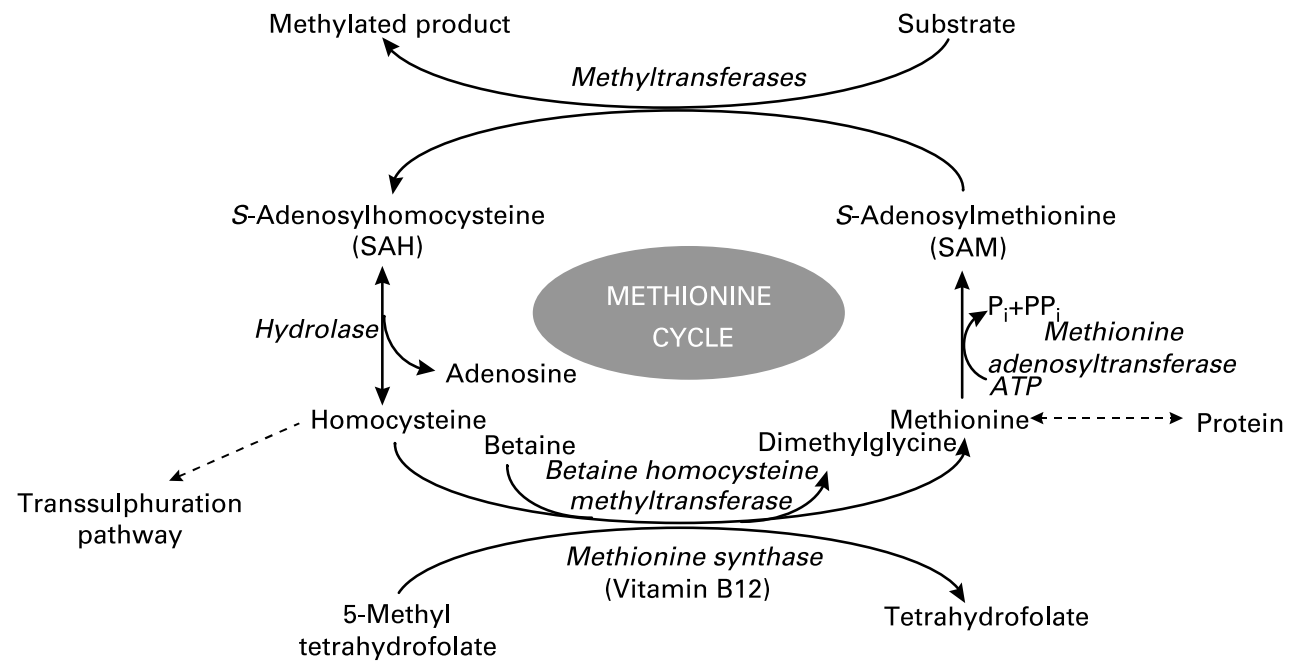

Fig. 1. Methionine cycle.

substrate for the synthesis of $S$-adenosylmethionine (SAM), a molecule which serves as a methyl donor in a wide range of transmethylation reactions involved in different aspects of cell life. By donating its methyl group, SAM is converted to $S$-adenosylhomocysteine (SAH), which in turn is hydrolysed to homocysteine and adenosine. Homocysteine can then be remethylated to methionine (via MS or additionally in liver by betaine homocysteine methyltransferase (BHMT)), thus completing the cycle, or be degraded via the transsulphuration pathway (Finkelstein, 1990).

On this basis, the present study was conducted to examine the effects of supranormal FA dietary supplementation on several biomarkers involved in the methionine cycle in weanling rats.

\section{Materials and methods}

\section{Animals and diets}

Thirty weanling male Wistar rats (initial weight approximately 50 g; Animal Service, Universidad San Pablo-CEU, Madrid, Spain), were classified into two groups on the basis of the experimental diet administered, FA supplemented (40 mg $\mathrm{FA} / \mathrm{kg}$ diet, $n$ 15) $v$. control (1 mg FA/kg diet, $n$ 15). The rats were given free access to the diets for 4 weeks, after a 1 -week adaptation period. Rats were individually housed in metabolic cages and were maintained in a room with a $12 \mathrm{~h}$ light/dark cycle, $20-23^{\circ} \mathrm{C}$, and with an appropriate ventilation system. Both diets were adjusted to rat requirements (National Research Council, 1995), and were based on the pure amino acid diet (17\% amino acid; Dyets, Bethlehem, PA, USA) (Walzem \& Clifford, 1988), differentiating in succinylsulphathiazole, which was not included. This is one of the most reliable systems to study the exclusive effect of dietary FA, without confounding factors, as has been demonstrated in several studies (Varela-Moreiras \& Selhub, 1992; VarelaMoreiras et al. 1995; Alonso-Aperte \& Varela-Moreiras, 1996; Achón et al. 1999, 2000, 2002; Roncalés et al. 2004). All rats were also given free access to water.
On day 29, rats were anaesthetized with $\mathrm{CO}_{2}$ and killed by decapitation.

The present study was approved by the Ethical Committee of Universidad San Pablo-CEU, according to the present law for laboratory animals.

\section{S-Adenosylmethionine and S-adenosylhomocysteine}

Hepatic SAM and SAH levels were determined by HPLC according to the method described by Fell et al. (1985), with some modifications (Miller et al. 1994). Aliquots of frozen liver (approximately $100 \mathrm{mg}$ ) were homogenized in four volumes of $0.4 \mathrm{M}$-perchloric acid, and then centrifuged at $10000 \mathrm{~g}, 4^{\circ} \mathrm{C}$, for $10 \mathrm{~min}$. The clear supernatants were removed, filtered, and appropriate aliquots were analysed for SAM and SAH.

\section{DNA methylation assay}

The capacity of hepatic DNA preparations to serve as methyl group acceptors was determined using the method of Christman et al. (1980) which was modified by replacing the DNA methylase from Friend erythroleukaemia cells with SssI methylase from Escherichia coli (New England Biolabs, Beverly, MA, USA). Briefly, DNA (2 $\mu \mathrm{g})$, SssI (4 U) and $\left[{ }^{3} \mathrm{H}-\right.$ methyl]SAM $(5 \mu \mathrm{Ci})$ in $20 \mu \mathrm{l}$ buffer containing $50 \mathrm{mM}-\mathrm{NaCl}$, $10 \mathrm{~mm}$-Tris-HCl, pH 8.0, and $10 \mathrm{~mm}$-EDTA were incubated for $3 \mathrm{~h}$ at $37^{\circ} \mathrm{C}$. The reaction was stopped by heating the mixture for $20 \mathrm{~min}$ at $65^{\circ} \mathrm{C}$. The mixture was then applied on to a disk of Whatman DE-81 paper and soaked in $50 \mathrm{ml} 5 \%$ $\mathrm{NaH}_{2} \mathrm{PO}_{4}$ for 45 min. Radioactivity retained on the disk was determined by scintillation counting using a non-aqueous scintillation fluor. The amount of radioactivity bound to a filter from an incubation mixture lacking only DNA was used as background and was subtracted from the values obtained with mixtures containing DNA. Because this is an inverse assay, a higher incorporation of ${ }^{3} \mathrm{H}$-methyl groups into DNA in the in vitro assay indicates a diminished in vivo methylation of DNA. 


\section{Homocysteine}

Serum homocysteine levels were determined using a Chromsystems Reagent Kit for HPLC analysis of homocysteine in serum (Chromsystems, Munich, Germany), which uses a simple isocratic HPLC system with an attached fluorescence detector $(\lambda$ Ex $385 \mathrm{~nm}$; $\lambda$ Em $515 \mathrm{~nm})$.

\section{Folate and vitamin $B_{12}$}

Serum folate and vitamin $\mathrm{B}_{12}$ levels were measured by using the Abbot Imx folate and vitamin $\mathrm{B}_{12}$ assays, respectively (Abbot Laboratories, Abbot Park, IL, USA), as previously reported (Roncalés et al. 2004).

\section{Vitamin $B_{6}$}

The determination of vitamin $\mathrm{B}_{6}$ serum levels was done using a Chromsystems Reagent Kit for HPLC analysis of vitamin $B_{6}$ in serum, which uses a simple isocratic HPLC system with an attached fluorescence detector $(\lambda$ Ex $300 \mathrm{~nm} ; \lambda$ Em $400 \mathrm{~nm})$.

\section{Enzymes}

Methionine adenosyltransferase (MAT), BHMT and MS activities were measured in liver extracts using radioenzymatic assays as described by Martín-Duce et al. (1988), Finkelstein \& Mudd (1967) and Keating et al. (1985), respectively. The results were expressed as mol product synthesized/ time per mg protein. In all three cases, total protein content in liver extracts was measured by the method of Bradford (1976).

\section{Serum biochemical markers}

Whole blood was collected from all rats and serum and plasma were separated by centrifugation, and kept at $-20^{\circ} \mathrm{C}$ until analysed. Aspartate aminotransferase, alanine aminotransferase, urea, glucose oxidase, creatinine, total bilirrubine and uric acid seric levels were determined with a Coulter chemistry profile analyser (Kemia Científica S.A., Madrid, Spain), as previously reported (Roncalés et al. 2004).

\section{Statistics}

Results are expressed as means and their standard errors. Differences in means were studied by one-way ANOVA. When ANOVA resulted in significant differences, multiple comparisons between means were studied by the Tukey test. Differences were considered significant at $P<0.05$ (SYSTAT Version 11; Systat, Chicago, IL, USA).

\section{Results}

General nutritional status

All the rats appeared to be healthy, and FA supplementation did not alter dietary intake (16.6 (SEM0.79) g/d supplemented rats $v .17 \cdot 1$ (SEM 0.78$) \mathrm{g} / \mathrm{d}$ control rats, NS) or body weight gain $(6 \cdot 1$ (SEM 0.25) g/d supplemented v. 6.2 (SEM 0.20) g/d control, NS). Consistent with previous studies (Achón et al. 1999, 2000, 2002), the folate-supplemented rats did not show a different pattern of growth after 4 weeks of the dietary intervention.

\section{Vitamins and homocysteine concentrations}

Levels of vitamins involved in the nutritional regulation of the methylation cycle were also examined (Table 1). As expected, supplementation with FA led to a significant increase in serum folate concentrations $(P<0 \cdot 001)$. In fact, supplemented animals had folate concentrations three times higher than that found in the control group. FA administration, conversely, did not affect serum vitamin $\mathrm{B}_{12}$ or $\mathrm{B}_{6}$ concentrations significantly.

On the other hand, plasma homocysteine concentrations were significantly lower in weanling rats receiving extra folate $(P<0 \cdot 01)$ when compared with control animals (Table 2$)$.

\section{Hepatic S-adenosylmethionine and S-adenosylhomocysteine concentrations, global DNA methylation and enzymatic activities}

Regarding the main biomarkers involved in the functioning of the methionine methylation cycle (Table 2), hepatic SAM concentrations were similar in both groups, supplemented and control. Hepatic SAH concentrations were not affected by folate supplementation. In consequence, the SAM:SAH concentration ratio ('methylation ratio') remained unchanged in the supplemented group compared to the control group. Accordingly, hepatic DNA global methylation did not show significant intergroup differences (Fig. 2). With respect to the enzymatic activities implicated in the methionine cycle, hepatic MAT activity was slightly reduced in the group of animals receiving extra folate, although differences were not

Table 1. Serum folate, vitamin $B_{12}$ and vitamin $B_{6}$ levels in weanling male Wistar rats fed folic acid-supplemented (40 mg/kg diet) or control $(1 \mathrm{mg} / \mathrm{kg})$ diets for $29 \mathrm{~d}$

(Mean values with their standard errors)

\begin{tabular}{|c|c|c|c|c|c|c|c|}
\hline \multirow[b]{2}{*}{ Group } & \multirow[b]{2}{*}{$n$} & \multicolumn{2}{|c|}{ Folate (ng/ml) } & \multicolumn{2}{|c|}{$\begin{array}{l}\text { Vitamin } B_{12} \\
(\mathrm{ng} / \mathrm{ml})\end{array}$} & \multicolumn{2}{|c|}{$\begin{array}{c}\text { Vitamin } B_{6} \\
(\mathrm{ng} / \mathrm{ml})\end{array}$} \\
\hline & & Mean & SEM & Mean & SEM & Mean & SEM \\
\hline Supplemented & 15 & $261 \cdot 0^{\star \star \star}$ & $2 \cdot 62$ & $1 \cdot 8$ & 0.05 & $359 \cdot 4$ & $20 \cdot 50$ \\
\hline Control & 15 & 71.9 & 5.93 & $2 \cdot 0$ & 0.10 & 371.9 & $30 \cdot 12$ \\
\hline
\end{tabular}

Mean value was significantly different from that of the control group: ${ }^{\star \star \star} P<0.001$. 
Table 2. Hepatic S-adenosylmethionine (SAM) and S-adenosylhomocysteine (SAH) concentrations, values for methylation ratio (SAM:SAH) and plasma homocysteine concentrations in weanling male Wistar rats fed on folic acid-supplemented $(40 \mathrm{mg} / \mathrm{kg}$ diet) or control ( $1 \mathrm{mg} / \mathrm{kg}$ diet) diets for $29 \mathrm{~d}$

(Mean values with their standard errors)

\begin{tabular}{|c|c|c|c|c|c|c|c|c|c|}
\hline \multirow[b]{2}{*}{ Group } & \multirow[b]{2}{*}{$n$} & \multicolumn{2}{|c|}{ SAM $(\mathrm{nmol} / \mathrm{g})$} & \multicolumn{2}{|c|}{$\mathrm{SAH}(\mathrm{nmol} / \mathrm{g})$} & \multicolumn{2}{|c|}{ SAM:SAH } & \multicolumn{2}{|c|}{$\begin{array}{l}\text { Homocysteine } \\
(\mathrm{nmol} / \mathrm{ml})\end{array}$} \\
\hline & & Mean & SEM & Mean & SEM & Mean & SEM & Mean & SEM \\
\hline Supplemented & 15 & 89.4 & 7.69 & $19 \cdot 4$ & $1 \cdot 11$ & 4.6 & 0.27 & $12 \cdot 4^{\star \star}$ & 0.42 \\
\hline Control & 15 & $80 \cdot 2$ & 3.72 & 18.9 & $1 \cdot 10$ & 4.5 & 0.43 & $15 \cdot 0$ & 0.68 \\
\hline
\end{tabular}

Mean value was significantly different from that of the control group: ${ }^{\star \star} P<0.01$.

significant ( $P=0.06$; Table 3$)$. Folate supplementation did not affect either hepatic MS or BHMT activities.

\section{Serum biochemical markers}

FA supplementation did not alter serum aspartate aminotransferase, alanine aminotransferase, urea, glucose oxidase, total bilirrubine and uric acid. However, serum creatinine concentrations were significantly lower $(P<0.05)$ in supplemented rats $(12.44$ (SEM 1.25$) \mu \mathrm{mol} / \mathrm{l})$ compared to control rats (16.71 (SEM 1.36) $\mu \mathrm{mol} / \mathrm{l}$; Table 4).

\section{Discussion}

Dietary surveys regarding folate generally deal with adults. In consequence, there is an urgent need to study the effects of long-term exposure to the presence of unmetabolized FA in growing individuals. On the basis of this lack of information,

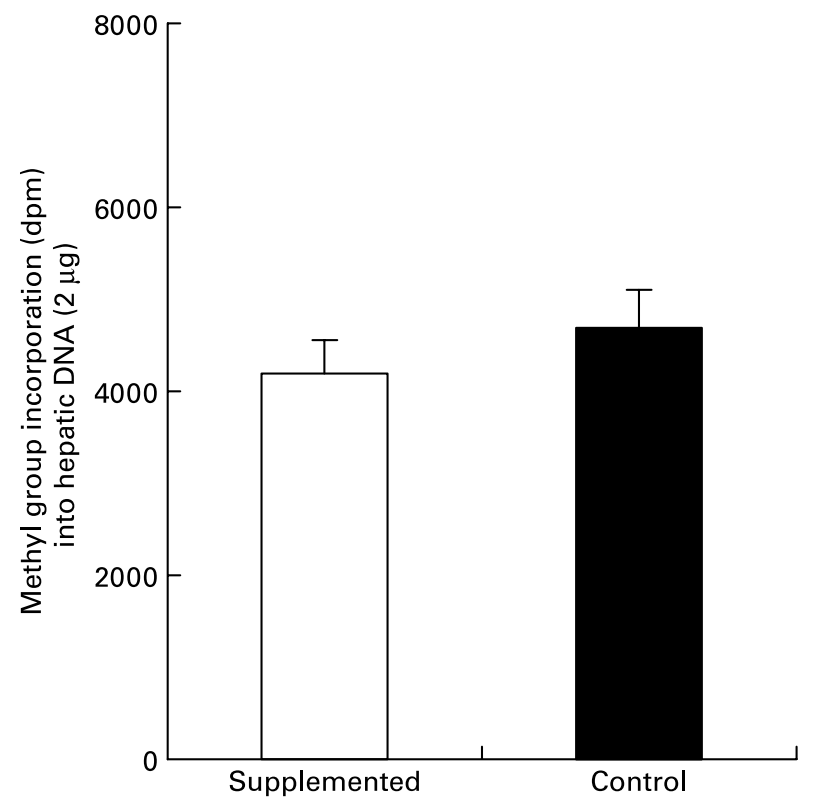

Fig. 2. Global DNA methylation in liver from weanling male Wistar rats fed on folic acid-supplemented $(40 \mathrm{mg} / \mathrm{kg}$ diet; $n$ 15) or control $(1 \mathrm{mg} / \mathrm{kg}$ diet; $n 15)$ diets for $29 \mathrm{~d}$. Values are means with their standard errors depicted by vertical bars. Results are expressed as methyl group (dpm) incorporation into DNA $(2 \mu \mathrm{g})$ isolated from rat liver. As an inverse assay, a greater in vitro incorporation of methyl groups indicates a lower degree of in vivo DNA methylation, and vice versa. we studied FA long-term effects on the methionine cycle in an animal model as weanling rats.

When general nutrition status was studied, we observed that FA supplementation did not affect normal dietary intake or growth in rats. This is in accordance with other studies which did not show an improved growth response when animals were fed with FA-enriched diets (Clifford et al. 1989; Achón et al. 1999, 2000, 2002). The present results, therefore, indicate an adequate growth with both FA levels in the diet. To our knowledge, there are no other comparable studies at present using our dietary FA level and experimental design.

Folate requirements are not specifically established in weanling rats. Still, the normal growth pattern in rats is well known to progress from early growth, that is predominantly by cellular hyperplasia and later by a combination of both hyperplasia and hypertrophy, eventually to a stage in which growth in most organs is primarily due to cellular hypertrophy (Winick \& Noble, 1965). According to this pattern, McNulty et al. $(1993,1995)$ reported an association between folate catabolism and hyperplasic growth situations as weaning and pregnancy. It has been proposed that this association is possibly related to vitamin utilization in cell replication. In the present study, serum FA was elevated by three-fold in supplemented animals compared to control and, according to the animals' growth, both diets were adequate to cover the rat requirements in a physiological situation of intense growth such as weaning.

SAM is essential in many transmethylation reactions and, therefore, in development and growth (Finkelstein, 1990). Folate deficiency has been shown to modulate SAM and SAH in the brain (Ordóñez \& Wutman, 1994; Varela-Moreiras et al. 1994), pancreas (Balaghi et al. 1992) and liver (Balaghi et al. 1993; Miller et al. 1994) in rats. Nevertheless, in the rodent model, a definite effect on SAM:SAH concentration ratio, also known as methylation ratio, after FA supplementation has not been established yet. In the present study, both groups of animals had similar hepatic SAM concentrations, despite the diet. SAH values also remained unchanged. In consequence, the value for the SAM:SAH concentration ratio was unaffected by the diet. In addition, hepatic MAT activity, which leads to SAM synthesis, did not change because of the dietary treatments. A reduction in MAT activity has been described in classic studies of hepatic injury in man (Cabrero et al. 1988) as well as in rats (Corrales et al. 1992). However, there are no published studies reporting the effects of supranormal amounts of folate on this critical enzymatic activity and in different physiological situations. We have 
Table 3. Hepatic methionine adenosyltransferase (MAT), methionine synthase (MS) and betaine homocysteine methyltransferase (BHMT) activities in weanling male Wistar rats fed folic acid-supplemented (40 mg/kg diet) or control $(1 \mathrm{mg} / \mathrm{kg})$ diets for $29 \mathrm{~d}$

(Mean values with their standard errors)

\begin{tabular}{|c|c|c|c|c|c|c|c|}
\hline Supplemented & 15 & $14 \cdot 31$ & 1.91 & $9 \cdot 18$ & 1.45 & $127 \cdot 95$ & $10 \cdot 39$ \\
\hline Control & 15 & $23 \cdot 21$ & $4 \cdot 13$ & $10 \cdot 26$ & 1.52 & $119 \cdot 74$ & $8 \cdot 14$ \\
\hline
\end{tabular}

also reported no effect on hepatic SAM and SAH concentrations after feeding aged rats with FA-enriched diets (Achón et al. 2002), although it has been frequently hypothesized that a greater methyl group supply could lead to more SAM synthesis. Additionally, in accord with the present findings, Sohn et al. (2003) have shown that moderate folate supplementation with $8 \mathrm{mg} / \mathrm{kg}$ diet did not modify colonic mucosal concentrations of SAM and SAH, and SAM:SAH ratios at any point after 5 weeks of dietary treatment. The present results, therefore, could indicate that very high levels of folate supplementation do not affect this stable SAM:SAH ratio and raises the speculation of whether or not available FA excess does really increase the efficiency of methylation in the liver. Moreover, it opens the question of the priority destination of the nutrient whether in deficiency or supranormal state.

Hepatic genomic DNA global methylation was not significantly affected by the diet. The study by Sohn et al. (2003) also reported that folate supplementation did not modulate genomic DNA methylation at any time. We have previously observed this same lack of effect of FA dietary supplementation in other physiological situations also related to growth, such as pregnancy (Achón et al. 2000). There is also a very interesting recent study by Choi et al. (2005) that showed increased hepatic DNA methylation in folate-supplemented aged rats ( $8 \mathrm{mg} \mathrm{FA} / \mathrm{kg}$ diet) compared with a folatedepleted group ( $0 \mathrm{mg} \mathrm{FA} / \mathrm{kg}$ diet) after 20 weeks of dietary treatment. In their study it is concluded that the ability to detect this effect of folate supplementation on DNA methylation is probably related to the age of the animals and/or the heightened accuracy of the method utilized to measure methylation. It is also very important to emphasize that in that same study differences in DNA methylation between supplemented animals and control ( $2 \mathrm{mg} \mathrm{FA} / \mathrm{kg}$ diet) were not detected at any point. Their results thus support our present results, since they provide evidence that both moderate and high folate supplementation do not involve an increase in DNA methylation. It seems then that dietary folate appears to be a determinant of DNA methylation under deficiency circumstances and not in supplementation or supranormal status.

FA supplementation resulted in a reduction for homocysteine concentration compared to control diets. The capacity of FA/folates to reduce homocysteine concentrations has been widely described in man (Selhub et al. 1993; Homocysteine Lowering Trialists' Collaboration, 2005) as well as in animal models. Indeed, the main concern at present is to ascertain the lowest dose of FA associated with the maximum reduction in homocysteine concentrations and to determine the additional relevance of vitamins $B_{12}$ and $B_{6}$ as well as $B_{2}$. It is interesting to remember that the present results reflect this homocysteine-lowering effect of the FA supplement even when comparing to data from animals fed with FA-sufficient diets. We have reported this same effect in pregnancy (Achón et al. 2000). The ability of FA to reduce even homocysteine reference values has been also described in man (Santhos-Kumar et al. 1997; Jacques et al. 1999). One of the main arguments used to support mandatory fortification is that elevated blood concentrations of homocysteine have been suggested as a modifiable risk factor for coronary artery disease, stroke and dementia (Clarke et al. 1998; Malinow et al. 2000; Homocysteine Studies Collaboration, 2002).

Homocysteine can be remethylated to methionine via MS (main pathway) or additionally in liver by BHMT. Dietary FA did not affect MS activity or BHMT activity, despite folate indeed being involved in this reaction. Vitamin $\mathrm{B}_{12}$, a cofactor involved in MS activity, also was unaffected. A reduction in MS activity in animals exposed to valproate, a well-known antifolate, has been reported (Alonso-Aperte et al. 1999). The activity of MS can be also reduced under circumstances that lead to deficiency of vitamin $B_{12}$ (Scott, 1992).

Table 4. Serum alanine aminotransferase (ALT), aspartate aminotransferase (AST), total bilirrubine, creatinine, urea, uric acid and glucose oxidase in weanling male Wistar rats fed on folic acid-supplemented $(40 \mathrm{mg} / \mathrm{kg}$ diet) or control (1 mg/kg diet) diets for $29 \mathrm{~d}$

(Mean values with their standard errors)

\begin{tabular}{|c|c|c|c|c|c|c|c|c|c|c|c|c|c|c|c|}
\hline \multirow[b]{2}{*}{ Group } & \multirow[b]{2}{*}{$n$} & \multicolumn{2}{|c|}{$\operatorname{ALT}(\mathrm{U} / \mathrm{l})$} & \multicolumn{2}{|c|}{ AST (U/l) } & \multicolumn{2}{|c|}{$\begin{array}{l}\text { Bilirrubine } \\
\text { (mg/l) }\end{array}$} & \multicolumn{2}{|c|}{$\begin{array}{l}\text { Creatinine } \\
(\mathrm{mg} / \mathrm{l})\end{array}$} & \multicolumn{2}{|c|}{ Urea (mg/l) } & \multicolumn{2}{|c|}{$\begin{array}{l}\text { Uric acid } \\
(\mathrm{mg} / \mathrm{l})\end{array}$} & \multicolumn{2}{|c|}{$\begin{array}{l}\text { Glucose oxi- } \\
\text { dase (mg/l) }\end{array}$} \\
\hline & & Mean & SEM & Mean & SEM & Mean & SEM & Mean & SEM & Mean & SEM & Mean & SEM & Mean & SEM \\
\hline Supplemented & 15 & 311 & 17.5 & 130 & $5 \cdot 9$ & $2 \cdot 7$ & 0.3 & $1.4^{\star}$ & 0.1 & 248 & 16 & 20 & 0.9 & 1850 & 57 \\
\hline Control & 15 & 293 & $15 \cdot 0$ & 126 & 5.9 & $2 \cdot 3$ & 0.4 & 1.9 & $0 \cdot 1$ & 271 & 13 & 19 & 0.9 & 1830 & 44 \\
\hline
\end{tabular}

Mean value was significantly different from that of the control group: ${ }^{\star} P<0.05$. 
However, the effect of high FA dietary supplementation has not been evaluated in other studies. Vitamin $B_{6}$, which is involved in the final conversion of homocysteine to glutatione through the transsulphuration pathway, also remained unchanged. This same effect has been described under moderate FA supplementation (Alonso-Aperte, 1997) in rats. Creatinine is a waste product in muscle metabolism and is a well-known biomarker for renal function. It is one of the numerous compounds requiring a methyl group from SAM for its synthesis. Additionally, serum creatinine has been positively related to homocysteine concentrations in healthy $28-$ 82-year-old women and men (Jacques et al. 2001) as well as dialysed patients (Bostom, 2000). Consistent with this pattern and together with the homocysteine-lowering effect, we observed a reduction in serum creatinine as a result of FA supplementation. In this sense, the present findings could confirm the ability of creatinine to be a good marker for homocysteine levels.

Since aspartate aminotransferase, alanine aminotransferase and billirubine were unchanged, we can conclude that FA supplementation did not induce adverse effects on these hepatic markers in the studied conditions. There are no other animal studies evaluating FA effects on these biomarkers. However, our group has actually described that FA supplementation not only did not damage but improved liver morphology in aged rats (Roncalés et al. 2004), which even had the same number of hepatocytes when compared to young animals. In the present study, we have also evaluated how folate supplementation may alter some biomarkers related to glycaemic metabolism and renal function. Specifically, either glucose, uric acid or urea seem to be unaffected by the dietary treatment.

On the basis of the observed results, we can conclude that there were no apparent adverse effects on one-carbon metabolism after FA supplementation in the studied conditions. More studies need to be undertaken in order to confirm the present results and to ascertain the possible mechanisms involved.

\section{Acknowledgements}

The study has been supported by a grant from Ministerio de Ciencia y Tecnología, Madrid, Spain (Ref. BFI2003-09538) and Universidad San Pablo-CEU, Madrid, Spain (Ref. USPCEU 02/15). Part of this work was presented at the VIII Meeting of the Spanish Nutrition Society, Murcia, 24-27 October 2001 [Achón M, Alonso-Aperte E \& Varela-Moreiras G (2001) Dietary folate supplementation in weanling and aged rats. Relationship with methionine metabolism. Nutrition 17, 1018].

\section{References}

Achón M, Alonso-Aperte E, Reyes L, Úbeda N \& Varela-Moreiras G (1999) High dietary folate supplementation affects gestational development and dietary protein utilization in rats. J Nutr 129, 1204-1208.

Achón M, Alonso-Aperte E, Reyes L, Úbeda N \& Varela-Moreiras G (2000) High-dose folic acid supplementation in rats: effects on gestation and the methionine cycle. Br J Nutr 83, 177-183.
Achón M, Alonso-Aperte E \& Varela-Moreiras G (2002) High dietary folate supplementation: effects on diet utilization and methionine metabolism in aged rats. $J$ Nutr Health Aging 6, 51-54.

Alonso-Aperte E (1997) Metabolismo de la metionina en rata gestante: efectos de la ingesta dietaria de ácido fólico y administración de valproato. Doctoral Thesis, San Pablo-CEU University, Madrid.

Alonso-Aperte E, Úbeda N, Achón M, Pérez-Miguelsanz J \& VarelaMoreiras G (1999) Impaired methionine synthesis and hypomethylation in rats exposed to valproate during gestation. Neurology $\mathbf{5 2}$, $750-756$.

Alonso-Aperte E \& Varela-Moreiras G (1996) Brain folates and DNA methylation in rats fed a choline deficient diet or treated with low doses of methotrexate. Int J Vitam Nutr Res 66, 232-236.

Bailey LB \& Berry RJ (2005) Folic acid supplementation and the occurrence of congenital heart defects, orofacial clefts, multiple births, and miscarriage. Am J Clin Nutr 81, Suppl., 1213S-1217S.

Bailey LB, Rampersaud GC \& Kauwell GP (2003) Folic acid supplements and fortification affect the risk for neural tube defects, vascular disease and cancer: evolving science. J Nutr 133, 1961S-1968S.

Balaghi M, Horne DW \& Wagner C (1992) Methyl group metabolism in the pancreas of folate deficient rats. J Nutr 122, 1391-1396.

Balaghi M, Horne DW \& Wagner C (1993) Hepatic one-carbon metabolism in early folate deficiency in rats. Biochem $J \mathbf{2 9 1}$, $145-149$.

Bostom AG (2000) Homocysteine: 'expensive creatinine' or important modifiable risk factor for arteriosclerotic outcomes in renal transplant recipients? J Am Soc Nephrol 11, 149-151.

Bradford MM (1976) A rapid and sensitive method for the determination of protein utilizing the principle of protein-dye binding. Anal Biochem 72, 248-254.

Cabrero C, Martín-Duce A, Ortiz P, Alemany S \& Mato JM (1988) Specific loss of high-molecular-weight form of $S$-adenosylmethionine synthetase in human liver cirrhosis. Hepatology $\mathbf{8}$, $1530-1534$.

Centers for Disease Control and Prevention (2004) Spina bifida and anencephaly before and after folic acid mandate - United States, 19951996 and 1999-2000. MMWR Morb Mortal Wkly Rep 53, 362-365.

Choi SW, Friso S, Keyes MK \& Mason JB (2005) Folate supplementation increases genomic DNA methylation in the liver of elder rats. Br J Nutr 93, 31-35.

Christman JK, Weich N, Schoenbrun B, Schneideman N \& Asc G (1980) Hypomethylation of DNA during differentiation of Friend erythroleukemia cells. J Cell Biol 86, 366-379.

Clarke R, Smith AD, Jobst KA, Refsum H, Sutton L \& Ueland PM (1998) Folate, vitamin B12 and serum total homocysteine levels in confirmed Alzheimer disease. Arch Neurol 11, 1449-1455.

Clifford AJ, Wilson DS \& Bills ND (1989) Repletion of folatedepleted rats with an aminoacid based diet supplemented with folic acid. J Nutr 119, 1956-1961.

Corrales F, Giménez A, Alvarez L, et al. (1992) S-Adenosyl methionine treatment prevents carbon tetrachloride-induced $S$-adenosylmethionine synthase inactivation and attenuates liver injury. Hepatology 16, 1022-1027.

Czeizel AE \& Dudas I (1992) Prevention of the first occurrence of neural-tube defects by periconceptional vitamin supplementation. $N$ Engl J Med 341, 1485-1490.

Fell D, Benjamin LE \& Steele RD (1985) Determination of adenosine and adenosyl derivatives of sulphur amino acids in rat liver by high liquid chromatography. J Chromatogr 345, 150-156.

Finkelstein JD (1990) Methionine metabolism in mammals. J Nutr Biochem 1, 228-237.

Finkelstein JD \& Mudd SH (1967) Transsulfuration in mammals: the methionine-sparing effect of cystine. J Biol Chem 242, 873-880.

Food and Drug Administration (1996) Food standards: amendment of standards of identity for enriched grain products to require addition 
of folic acid. Final rule. CFR 21, Parts 136, 137 and 139, $8781-8807$.

Giovanucci E, Stampfer MJ, Colditz GA, Hunter DJ, Fuchs C, Rosner BA, Speizer FE \& Willet WC (1998) Multivitamin use, folate, and colon cancer in women in the Nurses' Health Study. Ann Intern Med 129, 517-524.

Homocysteine Lowering Trialists' Collaboration (2005) Dose-dependent effects of folic acid on blood concentrations of homocysteine: a meta-analysis of the randomized trials. Am J Clin Nutr 82, $806-812$.

Homocysteine Studies Collaboration (2002) Homocysteine and risk of ischemic heart disease and stroke: a meta-analysis. JAMA $\mathbf{2 8 8}$, 2015-2022.

Institute of Medicine (editor) (1998) Dietary Reference Intakes for Thiamine, Riboflavin, Niacin, Vitamin B6, Folate, Vitamin B12, Panthotenic Acid, Biotin and Choline. Washington, DC: National Academy Press.

Jacques PF, Bostom AG, Wilson PW, Rich S, Rosenberg IH \& Selhub J (2001) Determinants of plasma total homocysteine concentration in the Framingham offspring cohort. Am J Clin Nutr 73, 613-621.

Jacques PF, Selhub J, Bostom A, Wilson P \& Rosenberg I (1999) The effect of folic acid fortification on plasma folate and total homocysteine concentrations. $N$ Engl J Med 340, $1449-1454$.

Keating JN, Weir DG \& Scott JM (1985) Demonstration of methionine synthetase activity in the intestinal mucosal cells of the rat. Clin Sci 3, 287-292.

Kim YI (2004) Will mandatory folic acid fortification prevent or promote cancer? Am J Clin Nutr 80, 1123-1128.

Kim YI, Salomon RN, Graeme-Cook F, Choi SW, Smith DE, Dallal GE \& Mason JB (1996) Dietary folate protects against the development of macroscopic colonic neoplasia in a dose responsive manner in rats. Gut 39, 732-740.

McNulty H, McPartlin JM, Weir DG \& Scott JM (1993) Folate catabolism is increased during pregnancy in rats. J Nutr $\mathbf{1 2 3}$, 1089-1093.

McNulty H, McPartlin JM, Weir DG \& Scott JM (1995) Folate catabolism is related to growth rate in weanling rats. J Nutr 125, 99-103.

Malinow MR, Duell PB, Irvin-Jones A, Upson BM \& Graf EE (2000) Increased plasma homocysteine after withdrawal of ready-to-eat breakfast cereal from the diet: prevention by breakfast cereal providing $200 \mu \mathrm{g}$ folic acid. J Am Coll Nutr 19, $452-457$.

Martín-Duce A, Ortiz P, Cabrero C \& Mato JM (1988) S-AdenosylL-methionine synthetase and phospholipid methyltransferase are inhibited in human cirrhosis. Hepatology 8, 65-68.

Miller JW, Nadeau MR, Smith J, Smith D \& Selhub J (1994) Folate deficiency-induced homocysteinemia in rats: disruption of $S$-adenosylmethionine's coordinate regulation of homocysteine metabolism. Biochem J 298, 415-419.
MRC Vitamin Study Research Group (1991) Prevention of neural tube defects: results of the Medical Research Council vitamin study. Lancet 338, 131-137.

National Research Council (1995) Nutrient requirements of the laboratory rat. In Nutrient Requirements of Laboratory Animals, 4th ed., pp. 11-80 [J Overton, editor]. Washington, DC: National Academy Press.

Ordóñez LA \& Wutman RJ (1994) Folic acid deficiency and methyl group metabolism in rat brain: effects of L-dopa. Arch Biochem Biophys 160, 372-376.

Persad VL, Van den Hof MC, Dubé JM \& Zimmer P (2002) Incidence of open neural tube defects in Nova Scotia after folic acid fortification. Can Med Assoc J 167, 241-245.

Ray JG (2004) Folic acid food fortification in Canada. Nutr Rev 62, Suppl. 6, Part 2, S35-S39.

Roncalés M, Achón M, Manzarbeitia F, Maestro de las Casas C, Ramírez C, Varela-Moreiras G \& Pérez-Miguelsanz J (2004) Folic acid supplementation for 4 weeks affects liver morphology in aged rats. $J$ Nutr 134, 1130-1133.

Santhos-Kumar CR, Deutsch JC, Ryder JW \& Kolhouse JF (1997) Unpredictable intraindividual variations in serum homocysteine levels on folic acid supplementation. Eur J Clin Nutr 51, 188-192.

Scott JM (1992) Folate-vitamin B12 interrelationships in the central nervous system. Proc Nutr Soc 51, 219-224.

Selhub J, Jacques PF, Wilson PW, Rush D \& Rosenberg IH (1993) Vitamin status and intake as primary determinants of homocysteinemia in an elderly population. $J$ Am Med Assoc 270, 2693-2698.

Sohn KJ, Stempak JM, Reid S, Shirwadkar S, Mason JB \& Kim YI (2003) The effect of dietary folate on genomic and p53-specific DNA methylation in rat colon. Carcinogenesis 24, 81-90.

Song J, Medline A, Mason JB, Gallinger S \& Kim YI (2000) Effects of dietary folate on intestinal tumorigenesis in the apcMin mouse. Cancer Res 60, 5434-5440.

Troen AM, Mitchell B, Sorensen B, et al. (2006) Unmetabolized folic acid in plasma is associated with reduced natural killer cell cytotoxicity among postmenopausal women. J Nutr 136, 189-194.

Varela-Moreiras G, Pérez-Olleros L, García-Cuevas L \& Ruiz-Roso B (1994) Effects of ageing on folate metabolism in rats fed a long term folate deficient diet. Int J Vitam Nut Res 64, 294-299.

Varela-Moreiras G, Ragel C \& Pérez de Miguelsanz J (1995) Choline deficiency and methotrexate treatment induces marked but reversible changes in hepatic folate concentrations, serum homocysteine and DNA methylation rates in rats. J Am Coll Nutr 14, 480-485.

Varela-Moreiras G \& Selhub J (1992) Long term folate deficiency alters folate content and distribution differentially in rat tissues. J Nutr 122, 986-991.

Walzem RL \& Clifford AJ (1988) Folate deficiency in rats fed diets containing free aminoacids or intact proteins. $J$ Nutr 118, 1089-1096.

Winick M \& Noble A (1965) Quantitative changes in DNA, RNA and protein during prenatal and postnatal growth in the rat. Dev Biol 12, 451-466. 